\title{
ASSESSING THE BIOACTIVITY AND ANTIOXIDATIVE PROPERTIES OF SOME COMPOUNDS ISOLATED FROM ABUTILON HIRTUM (LAM.)
}

\author{
MANAL MORTADY HAMED ${ }^{1 *}$, LAILA ABDEL-GHANY REFAHY ${ }^{1}$, MOHAMED SAYED ABDEL-AZIZ \\ ${ }^{1}$ Department of Medicinal Chemistry, Theodor Bilharz Research Institute, Giza, Egypt. ${ }^{2}$ Department of Microbial Chemistry, National \\ Research Center, Dokki, Cairo, Egypt. Email: manalayman90@yahoo.com
}

Received: 18 November 2016, Revised and Accepted: 14 December 2016

\section{ABSTRACT}

Objectives: The present study on the methanol extract of Abutilon hirtum (Lam.) [Malvaceae] afforded ten compounds. Findings from this assessment indicated that $A$. hirtum leaves possessed vast potential as medicinal product especially in liver cancer treatment.

Methods: Dried-powdered leaves were boiled under reflux in $10 \mathrm{~L}$ of petroleum ether for $8 \mathrm{hrs}$. After filtration, the solvent was evaporated; afforded $15 \mathrm{~g}$ of petroleum ether extract followed by boiling with reflux for $8 \mathrm{hrs}$ with chloroform, then filtration and the residue was evaporated to give $34 \mathrm{~g}$ chloroform extract. Ethyl acetate was added and refluxed for $8 \mathrm{hrs}$, then filtration and evaporation to give $31 \mathrm{~g}$ ethyl acetate extract. Finally the leaves were refluxed with $10 \mathrm{~L}$ of $85 \%$ aqueous $\mathrm{MeOH}$, after cooling, the solution was filtered and evaporated and the residue was $210 \mathrm{~g}$ methanol extract then the residue was dissolved in de-ionized water $(250 \mathrm{ml})$, then the salt was removed by adding excess methanol solution $(2.5 \mathrm{~L})$, and finally filtered. The cytotoxicity of the isolated compounds was evaluated towards HepG2 liver-carcinoma cell line using MTT assay, the antimicrobial activity was tested using the Disc agar plate method and the total antioxidant capacity was determined according to phosphomolybdenum method.

Results: The isolated compounds identified as methyl gallate, cuneataside E, bergapten, gallic acid, ellagic acid, epigallocatechin-3-O-gallate, kaempferol-3-O- $\alpha$-L-rhamnoside, benzyl-1-O- $\beta$-D-glucopyranoside, 2 (4-hydroxyphenyl)ethyl-O- $\beta$-D-glucopyranoside and $\beta$-sitosterol. All the isolated compounds are known; but they were isolated from Abutilon hirtum for the first time.

Conclusion: This report may serve as a footprint concerning the biological and pharmacological activities of $A$. hirtum leaves.

Keywords: Abutilon hirtum, Malvaceae, HepG2, Phenolics, Antioxidant.

(c) 2017 The Authors. Published by Innovare Academic Sciences Pvt Ltd. This is an open access article under the CC BY license (http://creativecommons. org/licenses/by/4. 0/) DOI: http://dx.doi.org/10.22159/ajpcr.2017.v10i3.16229

\section{INTRODUCTION}

Cancer, after cardiovascular disease, is the second main cause of death [1]. Treatment usually composed of various combinations of surgery, chemotherapy and radiation therapy, but regardless of these therapeutic options, cancer remains associated with high mortality. Natural and some synthetic compounds can prevent, curb, or reverse the headway of cancer. The enforcement and research for drugs obtained from plants have increased in recent years, while herbs and their constituents are generally known to be safe, either because of their traditional use without any legalized pernicious impact or because of reported toxicological studies [2]. Presently, there has been an increased advantage globally to identify antioxidant compounds that are pharmacologically potent and have low or no side effects for use in prophylactic medicine. The use of traditional medicine is widespread in Africa, and medicinal plants are still a senior source of natural antioxidants that might do as leads for the evolution of novel drug against free radical induced diseases. Abutilon [3] is a large genus of flowering plants in the mallow family, Malvaceae. It is distributed throughout the tropics and subtropics of the Americas, Africa, Asia, and Australia [4]. Various plants of Abutilon species are traditionally assumed for their varied pharmacological and medicinal properties and treatment of various ailments [5]. Furthermore, different plant parts contain specific phytoconstituents responsible for their biological activities. The flowers and leaves of some Abutilon species are applied as antiseptic and anti-inflammatory for urethritis, boils, and ulcers [6]. Several Abutilon species have been reported to consist of several constituents such as triterpenes, sterols [7], sesquiterpene lactones [8], flavonoids [9], phenolic acids [10], and essential oil [11]. The leaf extract of Abutilon indicum has been reported for the hepatoprotective activity [12]. Moreover, it is used to treat several disorders including diabetes mellitus [13]. Abutilon theophrasti Medic. has been demonstrated to have numerous pharmacological activities [14], such as expelling wind, detoxification, and anti-inflammatory activities; it is primarily used for otitis media, rheumatic pains, bruises, arthralgia, sprains, tinnitus, dysentery, and deafness treatments.

Abutilon hirtum (Lam.) sweet is a perennial herb, growing in Tropical Africa, Asia and Australia, naturized to India, South Florida, Mexico and South America [15]. In a previous publication, the lipid and mucilage contents of A. hirtum leaves possess cytotoxic activity [16]. The seeds are useful in expectorant, piles, laxative, in chronic cystitis, gonorrhea, and gleet [17-19]. A. hirtum has been taken up to give scientific evidence to the folklore demand on the hepatoprotective activity of the leaves in the form of decoction [20]. Decoction of the leaves used as mouth wash, bladder inflammations, wounds, and treatment of ulcers [21]. Alkaloids are reported from the roots of the plant [22]. Among this, the literature describes the presence of cholestane derivative in Abutilon bidentatum [23]. Secondary metabolites such as phenols, tannins, flavonoids [24], and sterols have been reported to possess antimicrobial, antioxidant and anticancer $[25,26]$ properties in many studies.

The objective of our present investigation was to determine the cytotoxicity, antimicrobial and antioxidant properties of some compounds isolated from A. hirtum by carrying out various experimental studies.

\section{MATERIALS AND METHODS}

\section{Plant materials}

A. hirtum (Lam.), Malvaceae, leaves were collected at May from El-Zohria garden, Cairo, Egypt. The plant was authenticated by Wafaa M. Amer, Professor of Taxonomy, Department of Botany, Faculty of Science, Cairo University, Giza, Egypt. Voucher specimens (Reg. No.: A1) were deposited at the herbarium, Medicinal Chemistry Department, Theodor Bilharz Research Institute, Giza, Egypt. 
General experimental procedures

Melting points were determined using a Melt-Apparatus (SMDP3 Stuart Scientific UK). Gas chromatography-mass spectrometry (GC-MS) data were determined on an electrospray ionization MS (ESI-MS) was measured on a Finnigan TSQ 700 GC/MS coupled with a Finnigan electrospray source. ${ }^{1} \mathrm{H}$ NMR $(300 \mathrm{MHz})$ and ${ }^{13} \mathrm{C}$ NMR $(75 \mathrm{MHz})$ data were obtained on JEOL GLM spectrometers relative to tetra methyl silane in dimethyl sulphoxide (DMSO)- $\mathrm{d}_{6}$. The absorbance measurements for antioxidant activity were recorded using the ultraviolet and visible (UV-vis) spectrophotometer Spectronic 601 (Milton Roy, USA). For column chromatography, silica gel (70-230 mesh) (Merck), Sephadex LH 20 (Pharmacia, Uppsala, Sweden), and polyamide 6S (Riedel de Darmstadt, Germany) were used. Paper chromatography (PC) was done on Whatman No. $1(57 \times 46 \mathrm{~cm})$, while thin layer chromatography (TLC) was carried out on readymade silica plates $\left(\mathrm{GF}_{254}\right.$, Merck) and visualized under UV light. The microplate reader (SunRise, TECAN, Inc., USA) was used to determine the number of viable cells and the percentage of viability. The solvents and reagents used herein were of analytical grade. Aluminum chloride, ferric chloride, sodium bicarbonate, sodium phosphate, ascorbic acid, and ammonium molybdate were purchased from Merck Chemical Co., all solvents and acids (petroleum ether, chloroform, ethyl acetate, methanol, n-butanol, sulfuric acid, acetic acid, aniline phthalate, pyridine- $d_{5}$, benzene, and DMSO) were purchased from Sigma-Aldrich Co. Human hepatocellular carcinoma (HepG2) cell line was obtained from the American type culture collection (ATCC, Rockville, MD). Fetal calf serum (FCS) (Hyclone, Logan, Utah, USA). Roswell Park Memorial Institute (RPMI), 1640 medium (Sigma), Chem. Co, St Louis, MO, USA.

\section{Equipment and chemicals for antimicrobial assays}

Nutrient agar medium (LAB M, UK), $\mathrm{Na} \mathrm{NO}_{3}$ (S. D. Fine-Chem. Ltd.), sucrose (Oxford), $\mathrm{MgSO}_{4}$ (S. D. Fine Chem. Ltd.), $\mathrm{FeSO}_{4}$ (S. D. Fine Chem. Ltd.), $\mathrm{KCl}$ (S. D. Fine Chem. Ltd.), $\mathrm{K}_{2} \mathrm{HPO}_{4}$ (MERCK), agar-agar bacto (S. D. Fine Chem. Ltd.), Staphylococcus aureus (G +ve bacteria) (ATCC 6538-P), Candida albicans (yeast) (ATCC 27853), Pseudomonas aeruginosa (G -ve bacteria) (ATCC 10231), and Aspergillus niger (fungi) (NRRL A-326). Low temperature incubator SHEL-LAB model 2005 shield on manufacturing. Inc, NUAJARE Biological safety cobient, LABSCO oven Laboratory Supply Company, Autoclave la Astell Heorson Germany, Olmon and Co. KG Germany, Refrigerator Toshiba (no frost model FR-GF40P). All the test microbes were obtained from the culture collection at Microbial Chemistry Department, National Research Center.

\section{Solvent systems}

n-BuOH:AcOH: $\mathrm{H}_{2} \mathrm{O}$ (4:1:5, top phase) (PC), (S1); $\mathrm{AcOH}: \mathrm{H}_{2} \mathrm{O}$ (15:85) (PC), S2; EtOAc:MeOH:H $\mathrm{H}_{2} \mathrm{O}$ (15:10:2) (TLC), S3; $\mathrm{CHCl}_{3}: \mathrm{MeOH}_{2} \mathrm{H}_{2} \mathrm{O}$ (8:2:0.3) (TLC), S4; $\mathrm{CHCl}_{3}: \mathrm{MeOH}(8: 2)$ (TLC) S5 and $\mathrm{CHCl}_{3}: \mathrm{MeOH}(9.5: 0.5)$ (TLC) S6.

\section{Statistical analysis}

All results were given as the mean \pm standard deviation of three replicates using SPSS v 13.0 program. The analysis of all experiments was analyzed by Microsoft Excel program for statistical significance.

\section{Evaluation of total antioxidant capacity (TAC)}

The TAC of each sample was determined according to phosphomolybdenum method according to Prieto et al., 1999, using ascorbic acid as a standard. In this method, $0.5 \mathrm{ml}$ of each sample $(200 \mu \mathrm{g} / \mathrm{ml})$ in methanol mixed in dried tubes with $5 \mathrm{ml}$ of standard reagent solution containing $(0.6 \mathrm{M}$ sulfuric acid, $4 \mathrm{mM}$ ammonium molybdate and $28 \mathrm{mM}$ sodium phosphate). The tubes containing the reaction solution mixture were capped and incubated in a thermal block at $95^{\circ} \mathrm{C}$ for 90 minutes. The samples had cooled at room temperature; then, the absorbance was measured at $695 \mathrm{~nm}$ using a UV-vis spectrophotometer Spectronic 601 against a blank. The blank consisted of all reagents solvents and without the sample and it was incubated under the same conditions. All experiments were carried out in triplicate. The antioxidant activity of the compounds was expressed as the number of ascorbic acid equivalents (AAE) [27].
Cytotoxic activity assay of liver carcinoma cell line (HepG2)

The cells were grown on RPMI-1640 medium supplemented with $10 \%$ inactivated fetal calf serum FCS and $50 \mu \mathrm{g} / \mathrm{ml}$ gentamycin. The cells were maintained at $37^{\circ} \mathrm{C}$ in a humidified atmosphere with $5 \% \mathrm{CO}_{2}$ and were subcultured two to three times a week. For antitumor assays, the tumor cell lines were suspended in medium at concentration $5 \times 10^{4}$ cell/well in Corning ${ }^{\circledR}$ 96-well tissue culture plates and then incubated for $24 \mathrm{hrs}$. The tested compounds were then added into 96-well plates (six replicates) to achieve eight concentrations for each compound. Six vehicle controls with media or $0.5 \%$ DMSO were run for each 96 well plate as a control. After incubating for $24 \mathrm{hrs}$, the numbers of viable cells were determined by the MTT test. Briefly, the media was removed from the 96 well plates and replaced with $100 \mu \mathrm{l}$ of fresh culture RPMI 1640 medium without phenol red then $10 \mu \mathrm{l}$ of the $12 \mathrm{mM}$ MTT stock solution (5 mg of MTT in $1 \mathrm{ml}$ of phosphate buffered saline) to each well including the untreated controls. The 96 well plates were then incubated at $37^{\circ} \mathrm{C}$ and $5 \% \mathrm{CO}_{2}$ for $4 \mathrm{hrs}$. An $85 \mu \mathrm{l}$ aliquot of the media was removed from the wells, and $50 \mu \mathrm{l}$ of DMSO was added to each well and mixed thoroughly with the pipette and incubated at $37^{\circ} \mathrm{C}$ for 10 minutes. Then, the optical density was measured at $590 \mathrm{~nm}$ with the microplate reader to determine the number of viable cells and the percentage of viability was calculated as [1-(ODt/ODc)] $\times 100 \%$, where ODt is the mean optical density of wells treated with the tested sample and ODc is the mean optical density of untreated cells. The relation between surviving cells and drug concentration is plotted to get the survival curve of each tumor cell line after treatment with the specified compound. The $50 \%$ inhibitory concentration $\left(\mathrm{IC}_{50}\right)$, the concentration required to cause toxic effects in $50 \%$ of intact cells was estimated from graphic plots of the dose response curve for each conc. using GraphPad Prism software (San Diego, CA. USA) [28].

\section{Antimicrobial activity bioassay}

Disc agar plate method was done to evaluate the antimicrobial activity of methanol extract from A. hirtum plant and the isolated pure compounds. The antimicrobial activities of 0.5 -cm-diameter filter paper disc saturated with about $1 \mathrm{mg}$ sample were tested against four different microbial strains, i.e., $S$. aureus ( $\mathrm{G}+\mathrm{ve}$ bacteria), P. aeruginosa ( $\mathrm{G}$-ve bacteria), C. albicans (yeast), and A. niger (fungi). Both bacterial and yeast test microbes were grown on nutrient agar (DSNZ 1) medium (g/L): Beef extract (3), agar (20) and peptone (10), whereas fungal test microbe was grown on Szapek-Dox (DSMZ 130) medium (g/L): Sucrose (30), $\mathrm{MgSO}_{4} .7 \mathrm{H}_{2} \mathrm{O}(0.5), \mathrm{NaNO}_{3}$ (3), $\mathrm{KCl}$ (0.5), $\mathrm{FeSO}_{4} .7 \mathrm{H}_{2} \mathrm{O}(0.001), \mathrm{K}_{2} \mathrm{HPO}_{4}(1)$, and agar (20). The culture of each microorganism was diluted by sterile distilled water to $10^{7}$ to $10^{8} \mathrm{CFU} / \mathrm{ml}$ to be used as inoculum. $1 \mathrm{ml}$ of the previous inoculum was used to inoculate $1 \mathrm{l}$ of agar medium (just before solidification) then poured in Petri dishes $(10 \mathrm{~cm}$ diameter containing $25 \mathrm{ml})$. Discs ( $5 \mathrm{~mm}$ diameter) were placed on the surface of the agar plates previously inoculated with the test microbe and incubated for $24 \mathrm{hrs}$ for bacteria and yeast but for $48 \mathrm{hrs}$ for fungus at $37^{\circ} \mathrm{C}$ and $30^{\circ} \mathrm{C}$, respectively [29].

\section{Acid hydrolysis of compounds 2, 7, 8 and 9}

A solution of each compound (5 mg) was hydrolyzed in aqueous solution of $2 \mathrm{M} \mathrm{HCl}(5 \mathrm{ml})$ was heated in a water bath at $100^{\circ} \mathrm{C}$ for $2 \mathrm{hrs}$. The solution mixture was evaporated in a rotatory evaporator in vacuum to dryness and was dissolved in $\mathrm{MeOH}$, then the mixture was partitioned between chloroform and water using separating funnel. The chloroform extract was evaporated under reduced pressure then crystallized to give the aglycone. The sugar was extracted with pyridine from the aqueous layer after neutralized with $\mathrm{NaHCO}_{3}$, then filtered and concentrated. The aglycone was detected on PC using CoPC with authentic aglycone samples and visualized under UV and with $\mathrm{NH}_{3}$ vapor. Sugar moieties were detected on silica gel TLC plates with EtOAc:MeOH: $\mathrm{H}_{2} \mathrm{O}: \mathrm{AcOH}$ (13:3:3:4) using aniline phthalate in n-butanol (freshly prepared), as a spraying reagent. Furthermore, further confirmation for the sugar was carried out on PC (Whatmann paper No. 1), via solvent system (n-butanol:pyridine- $d_{5}:$ water [10:3:3]), then the sugar spots were detected by spraying with freshly prepared aniline phthalate sugar reagent. 


\section{Extraction and isolation}

Dried-powdered leaves (1600 g) were boiled under reflux in $10 \mathrm{~L}$ of petroleum ether for $8 \mathrm{hrs}$. After filtration, the solvent was evaporated; afforded $15 \mathrm{~g}$ of petroleum ether extract and the leaf powder dried, then boiled with reflux for $8 \mathrm{hrs}$ with chloroform, then filtration and the residue was evaporated to give $34 \mathrm{~g}$ chloroform extract. Ethyl acetate was added and refluxed for $8 \mathrm{hrs}$, then filtration and evaporation to give $31 \mathrm{~g}$ ethyl acetate extract. Finally, the leaves were refluxed with $10 \mathrm{~L}$ of $85 \%$ aqueous $\mathrm{MeOH}$, after cooling, the solution was filtered and evaporated, and the residue was $210 \mathrm{~g}$ methanol extract then the residue was dissolved in de-ionized water $(250 \mathrm{ml})$, then the salt was removed by adding excess methanol solution $(2.5 \mathrm{~L})$, and finally filtered. The filtrate was dried to give $(96 \mathrm{~g}$ ) extract, which was chromatographed on polyamide column chromatography CC $(120 \times 7 \mathrm{~cm}, 355 \mathrm{~g})$ eluted successively with $0,25,50,75$, and $100 \% \mathrm{MeOH}$ in $\mathrm{H}_{2} \mathrm{O}$, each $1 \mathrm{~L}$ to give five fractions (A: $13.5 \mathrm{~g}, \mathrm{~B}: 3.73 \mathrm{~g}, \mathrm{C}, 5.7 \mathrm{~g}, \mathrm{D}: 4.0 \mathrm{~g}$, and E: $1.4 \mathrm{~g}$, respectively). Fraction $\mathrm{A}$ was applied to a silica gel $\mathrm{CC}$ eluted with a gradient of $\mathrm{MeOH}: \mathrm{H}_{2} \mathrm{O}(15: 100)$ to afford 30 subfraction (each $20 \mathrm{ml}$ ). Sub fraction [6-14] (219 mg), eluted with $\mathrm{CHCl}_{3}: \mathrm{MeOH}$ (5.5:4.5) on silica gel CC, were further separated by Sephadex LH-20 CC eluted with a gradient of $\mathrm{MeOH}: \mathrm{H}_{2} \mathrm{O}$ (from 2:8 to 10:0) to yield $28 \mathrm{mg}$ of compound 7. Subfraction [15-30] (257 mg), eluted with $\mathrm{CHCl}_{3}: \mathrm{MeOH}$ (5:5), were further separated by Sephadex LH-20 CC eluted with a gradient of $\mathrm{MeOH}: \mathrm{H}_{2} \mathrm{O}$ (from 3:7 to 10:0) to yield compound 6 (54 mg). Fraction B eluted with $\mathrm{CHCl}_{3}: \mathrm{MeOH}: \mathrm{H}_{2} \mathrm{O}$ (7:3:0-7:3:5), was further separated on silica gel CC eluted with a gradient of $\mathrm{CHCl}_{3}: \mathrm{MeOH}: \mathrm{H}_{2} \mathrm{O}$ (8:2:0-7:3:5), and precipitated with acetone to afford compound 2 . Fraction $\mathrm{C}$ eluted with $\mathrm{MeOH}: \mathrm{H}_{2} \mathrm{O}$ (7.5:2.5) and applied on polyamide CC, then was purified on Sephadex LH-20 CC yielding compounds 4 (56 mg), 5 (24 mg) and $1(16 \mathrm{mg})$. Fraction D eluted with $\mathrm{CHCl}_{3}: \mathrm{MeOH}_{\mathrm{H}} \mathrm{O}$ (7:3:0.3) to give 22 subfraction, were also purified on repeated silica gel column chromatography over successively eluted with $\mathrm{CHCl}_{3}$ and $\mathrm{CHCl}_{3}: \mathrm{MeOH}$ with increasing contents of methanol afforded compound 8 (45 mg) and 9 (32 mg). Fraction E was subjected to CC over silica gel using gradient elution with $\mathrm{C}_{6} \mathrm{H}_{6}$ :EtOAc (10:0-3:7) afforded 24 subfraction (each $15 \mathrm{ml}$ ) possess mixture of compounds; subfraction [2-9] subjected to a preparative silica gel chromatography afforded compound 3 (27 mg), then subfractions [10-24] was re-purified on Sephadex LH-20 CC and eluted with $\mathrm{MeOH}: \mathrm{H}_{2} \mathrm{O}$ (9.5:0.5) affording compound 10 (36 mg).

\section{RESULTS AND DISCUSSION}

Column chromatographic separation of the $85 \%$ methanol extract of $A$. hirtum leaves led to the isolation of ten compounds, nine of them are phenolics, the structure of the isolated compounds were established by spectroscopic analysis. The isolated compounds identified as methyl gallate, cuneataside E, bergapten, gallic acid, ellagic acid, epigallocatechin-3-O-gallate (EGCG), kaempferol-3- $O$ - $\alpha$-L-rhamnoside, benzyl-1-O- $\beta$-D-glucopyranoside, $\quad 2$ (4-hydroxyphenyl)ethyl- $O$ - $\beta$-Dglucopyranoside, and $\beta$-sitosterol (Fig. 1). All the isolated compounds are known, but they were isolated from $A$. hirtum for the first time.

Compound 1 (methyl gallate): It is isolated as white granules, m.p. $202^{\circ} \mathrm{C}$, $\mathrm{R}_{\mathrm{f}}: 0.52$ (S5), ESI-MS mass spectra showed a molecular ion peak at $\mathrm{m} / \mathrm{z} 184.9(\mathrm{M}+\mathrm{H})^{+} ;{ }^{1} \mathrm{H}$ NMR showed a singlet signal in aromatic zone at $\delta 7.3(2 \mathrm{H}, \mathrm{s}, \mathrm{H}-2$ and $\mathrm{H}-6)$ which indicated that the compound should be symmetrical and have four constituent groups. A signal appeared at $\delta 3.3(3 \mathrm{H}, s, \mathrm{OMe})$ indicated presence of methoxyl group. ${ }^{13} \mathrm{C}$ NMR give six signals at $\delta 167.5(\mathrm{C}=0), 145.7(\mathrm{C}-3, \mathrm{C}-5), 138.4(\mathrm{C}-4), 120.2(\mathrm{C}-1)$, $109.9(\mathrm{C}-2, \mathrm{C}-6)$, and $51.2\left(\mathrm{OCH}_{3}\right)$. The chemical shifts of ${ }^{1} \mathrm{H}$ and ${ }^{13} \mathrm{C}$ NMR spectra matched the data reported of methyl gallate previously isolated from Anacardium occidentale L [30].

Compound 2 (cuneataside E) (4-[4 $\beta$ - $O-\beta$-D-apiofuranosyl- $\left(1^{\prime \prime} \rightarrow 6^{\prime}\right)-\beta$-Dglucopyranosyl-2,6,6-trimethyl-1-cyclohexan-1-yl]-butan-2-one): It is isolated as a white powder, m.p. $254^{\circ} \mathrm{C}, \mathrm{R}_{\mathrm{f}}: 0.61$ (S3), ESI-MS mass spectra showed molecular ion at m/z $505(\mathrm{M}+\mathrm{H})^{+} .{ }^{1} \mathrm{H}$ NMR spectrum data show presence of methyl groups at $\delta 0.83\left(3 \mathrm{H}, \mathrm{s}, \mathrm{CH}_{3}-11\right), \delta 1.00\left(3 \mathrm{H}, \mathrm{s}, \mathrm{CH}_{3}-12\right)$, $\delta 1.22\left(3 \mathrm{H}, \mathrm{s}, \mathrm{CH}_{3}-13\right), \delta 1.84,1.43(2 \mathrm{H}, m, \mathrm{H}-2 \alpha$ and $\beta), \delta 2.48,2.08$ $(2 \mathrm{H}, m, \mathrm{H}-4 \alpha$ and $\beta$ ), $\delta 2.33$ ( $2 \mathrm{H}, m, \mathrm{H}-7), \delta 2.96$ ( $2 \mathrm{H}, m, \mathrm{H}-8)$. Anomeric proton of glucose molecule appears at $\delta 5.16$ (anomeric-glu) and the rest of glucose proton appears at $\delta 3.15-3.90$, another anomeric protons at $\delta 5.32$ (anomeric-api), these data confirmed by ${ }^{13} \mathrm{C}$ NMR data (Table 1). In complete acid hydrolysis gave glucose and apiose in the aqueous phase. Both ${ }^{1} \mathrm{H}$ and ${ }^{13} \mathrm{C}$ NMR data matched with ionone glycoside named cuneataside E isolated from Sargentodoxa cuneata stem [31].

Compound 3 (bergapten): It is isolated as white powder, m.p. $180-185^{\circ} \mathrm{C}$, $\mathrm{R}_{\mathrm{f}}: 0.46$ [S6], ESI-MS mass spectra give peak of molecular ion at $\mathrm{m} / \mathrm{z}$ at $217(\mathrm{M}+\mathrm{H})^{+},{ }^{1} \mathrm{H}$ NMR data showed signals at $\delta 8.02(1 \mathrm{H}, d, J=10 \mathrm{~Hz}$, $\mathrm{H}-4), \delta 7.67\left(1 \mathrm{H}, d, J=2.5 \mathrm{~Hz}, \mathrm{H}-2^{\prime}\right), \delta 7.06(1 \mathrm{H}, s, \mathrm{H}-8), \delta 7.03(1 \mathrm{H}, d$, $\left.J=2.0 \mathrm{~Hz}, \mathrm{H}-3^{\prime}\right), \delta 3.75$ (3H, s, OMe). ${ }^{13} \mathrm{C}$ NMR (Table 1) showed signals characteristic of a furanocoumarin bergapten which previously isolated from Portulaca oleracea [32].

Compound 4 (gallic acid): It is isolated as buff needles, m.p. $255^{\circ} \mathrm{C}$, $\mathrm{R}_{\mathrm{f}}: 0.49$ [S2], it showed similarity with methyl gallate spectrum data where; ESI-MS mass spectra give a molecular ion at m/z $303(\mathrm{M}+\mathrm{H})^{+}$ and it showed a single signal in aromatic region in ${ }^{1} \mathrm{H}$ NMR spectrum at $\delta 7.6(2 \mathrm{H}, s, \mathrm{H}-2$ and $\mathrm{H}-6) \cdot{ }^{13} \mathrm{C}$ NMR data showed five signals in aromatic region identical to that of gallic acid, $\delta 168.2(\mathrm{C}=0)$, 145.7 (C-3, 5), 138.5 (C-4), 121.8 (C-1) and 109.6 (C-2, 6). Gallic acid is widely distributed in tannin containing plants [33]

Compound 5 (ellagic acid): It is obtained as gray crystals, m.p. $353^{\circ} \mathrm{C}, \mathrm{R}_{\mathrm{f}}$ : 0.67 [S2], ESI-MS mass spectra give a molecular ion at m/z $303(\mathrm{M}+\mathrm{H})^{+}$, ${ }^{1} \mathrm{H}$ NMR showed one singlet signal in aromatic region at $\delta 7.6(2 \mathrm{H}, s$, aromatic-H). It gives blush green color with ferric chloride. According to mixed m.p. and color reaction on PC comparable with authentic sample; compound 5 identified as ellagic acid [34].

Compound 6 (EGCG): It is isolated as cream powder m.p. $212^{\circ} \mathrm{C}, \mathrm{R}_{\mathrm{f}}$ : 0.26 (S1), 0.74 [S2], ESI-MS mass spectra give a molecular ion at $\mathrm{m} / \mathrm{z} 459(\mathrm{M}+\mathrm{H})^{+},{ }^{1} \mathrm{H}$ NMR showed signals at $\delta 7.7\left(4 \mathrm{H}, s, \mathrm{H}-2,6^{\prime}\right.$ and H-2", 6"), $\delta 7.1$ (1H, d, J=2.0 Hz, H-6), $\delta 6.6$ (1H, $d, J=2.0 \mathrm{~Hz}, \mathrm{H}-8), \delta$ $5.32(1 \mathrm{H}, m, \mathrm{H}-3), \delta 4.90(1 \mathrm{H}, d, J=5.6 \mathrm{~Hz}, \mathrm{H}-2), \delta 1.99(2 \mathrm{H}, m, \mathrm{H}-4)$, these data confirmed by ${ }^{13} \mathrm{C}$ NMR data (Table 1 ) which suggested that compound 6 was EGCG [33].

Compound 7 (kaempferol-3-O- $\alpha$-L-rhamnoside): It is isolated as yellow powder, m.p. $278^{\circ} \mathrm{C}, \mathrm{R}_{\mathrm{f}}: 0.70$ [S2], ESI-MS give a molecular ion at $\mathrm{m} / \mathrm{z}$ $400(\mathrm{M}+\mathrm{H})^{+},{ }^{1} \mathrm{H}$ NMR showed signals in aromatic region similar to that of kampferol at $\delta 7.69\left(2 \mathrm{H}, d, J=8.0 \mathrm{~Hz}, \mathrm{H}-2^{\prime}\right.$ and $\left.\mathrm{H}-6^{\prime}\right), \delta 6.89(2 \mathrm{H}, d$, $J=8.0 \mathrm{~Hz}, \mathrm{H}-3^{\prime}$ and $\left.\mathrm{H}-5^{\prime}\right), \delta 6.65(1 \mathrm{H}, d, J=2.5 \mathrm{~Hz}, \mathrm{H}-8), \delta 6.40(1 \mathrm{H}, d$, $J=2.5 \mathrm{~Hz}, \mathrm{H}-6)$ in addition to signal at $\delta 4.95(1 \mathrm{H}, \mathrm{brs}$, anomeric proton), $\delta 1.13(3 \mathrm{H}, d, J=6.1 \mathrm{~Hz}, \mathrm{Me})$; characteristic to rhamnose. Acid hydrolysis revealed the presence of rhamnose in the aqueous portion. ${ }^{13} \mathrm{C}$ NMR (Table 1) agree with the previous data and suggested that compound 7 identified as kaempferol-3-O- $\alpha$-L-rhamnoside which previously isolated from other plants [33,35].

Compound 8 (benzyl-1- $O$ - $\beta$-D-glucopyranoside): It is isolated as white needles, m.p. $210-215^{\circ} \mathrm{C}, \mathrm{R}_{\mathrm{f}}$ : 0.86 (S1), ESI-MS mass spectra gave molecular ion at $\mathrm{m} / \mathrm{z} 271(\mathrm{M}+\mathrm{H})^{+},{ }^{1} \mathrm{H}$ NMR showed multiplet signal at $\delta$ 7.70-7.67 (5H, $m, \mathrm{H}-2,3,4,5,6)$, characteristic for mono-substituted aromatic ring. It also showed many signals at $\delta 4.14(1 \mathrm{H}, d, J=11.8 \mathrm{~Hz}$, $\mathrm{H}-7 \mathrm{a}), \delta 4.20(1 \mathrm{H}, d, J=11.8 \mathrm{~Hz}, \mathrm{H}-7 \mathrm{~b})$ and $4.0-3.37$ (six glucose protons). ${ }^{13} \mathrm{C}$ NMR spectrum (Table 1 ), showed 13 signals, two oxymethylene at $\delta 70.5\left(\mathrm{OCH}_{2}-7\right)$ and $\delta 60.3\left(\mathrm{CH}_{2} \mathrm{OH}\right.$, glu $)$, five oxymethines $(\mathrm{CHOH}, \mathrm{glu})$, five methane (aromatic $\mathrm{CH}$ ) and one quaternary carbon (aromatic $\mathrm{C}$ ), it suggest presence of mono-substituted aromatic ring and hexose sugar. Complete acid hydrolysis indicates that the sugar was glucose; these data suggested that compound 8 is benzyl-1- $O-\beta$-D-glucopyranoside; the compound was previously isolated from Averrhoa carambola L. [36].

Compound 9 (2(4-hydroxyphenyl)ethyl glucopyranoside): The compound was isolated as a reddish brown powder m.p. $160^{\circ} \mathrm{C}, \mathrm{R}_{\mathrm{r}}: 0.62$ (S5), ESI-MS mass spectra gave molecular ion at m/z $271(\mathrm{M}+\mathrm{H})^{+},{ }^{1} \mathrm{H}$ NMR give signals indicative to p-hydroxy phenyl unit at $\delta 7.68(2 \mathrm{H}, d$, 
Table 1: ${ }^{13} \mathrm{C}$ NMR of compounds 2, 3, 6, 7, 8 and $9(300,75$ MHz, DMSO-d 6$)$

\begin{tabular}{|c|c|c|c|c|c|c|}
\hline Carbon number & Compound 2 & Compound 3 & Compound 6 & Compound 7 & Compound 8 & Compound 9 \\
\hline 1 & 40.1 & - & - & & 137.5 & 130.5 \\
\hline 2 & 46.9 & 161.2 & 72.2 & 156.6 & 125.7 & 131.3 \\
\hline 3 & 76.0 & 112.6 & 70.3 & 133.4 & 127.0 & 116.7 \\
\hline 4 & 40.4 & 138.7 & 30.0 & 177.5 & 128.3 & 157.4 \\
\hline 5 & 127.4 & 150.0 & 156.2 & 162.0 & 127.0 & 116.7 \\
\hline 6 & 138.2 & 112.9 & 94.3 & 99.0 & 125.7 & 131.1 \\
\hline 7 & 24.0 & 158.6 & 156.9 & 165.4 & 70.5 & 37.0 \\
\hline 8 & 46.5 & 92.7 & 95.7 & 93.7 & & 72.9 \\
\hline 9 & 220.0 & 152.6 & 156.9 & 156.4 & & \\
\hline 10 & 31.9 & 106.7 & 95.7 & 103.7 & & \\
\hline 11 & 30.1 & & & & & \\
\hline 12 & 31.3 & & & & & \\
\hline \multirow{2}{*}{13} & 21.5 & & & & & \\
\hline & Glc & & & & Glc & Glc \\
\hline $1^{\prime}$ & 101.5 & & 127.2 & 121.2 & 101.3 & 105.1 \\
\hline $2^{\prime}$ & 75.7 & 144.5 & 97.6 & 115.3 & 78.0 & 75.5 \\
\hline $3^{\prime}$ & 78.3 & 105.3 & 145.8 & 145.3 & 75.6 & 78.2 \\
\hline $4^{\prime}$ & 72.2 & & 133.4 & 147.9 & 72.6 & 70.8 \\
\hline $5^{\prime}$ & 76.2 & & 145.8 & 116.2 & 77.5 & 75.9 \\
\hline \multirow[t]{2}{*}{$6^{\prime}$} & 69.4 & & 97.6 & 121.6 & 62.3 & 65.4 \\
\hline & Api & & & Rham & & \\
\hline 1" & 110.5 & & 120.2 & 101.7 & & \\
\hline 2" & 78.5 & & 109.0 & 72.9 & & \\
\hline 3" & 80.1 & & 146.5 & 73.2 & & \\
\hline 4" & 75.9 & & 139.9 & 71.5 & & \\
\hline 5" & 65.8 & & 146.5 & 69.0 & & \\
\hline 6" & & & 109.0 & 18.4 & & \\
\hline 7"' & & & 165.4 & & & \\
\hline $\mathrm{OMe}$ & & 61.4 & & & & \\
\hline
\end{tabular}

$\delta$ in ppm

$J=8.4 \mathrm{~Hz}, \mathrm{H}-2$ and $\mathrm{H}-6), \delta 6.65(2 \mathrm{H}, d, J=8.4 \mathrm{~Hz}, \mathrm{H}-3$ and $\mathrm{H}-5), \delta 3.72$ and $4.12(2 \mathrm{H}, m, \mathrm{H}-8), \delta 2.20$ ( $2 \mathrm{H}, \mathrm{m}, \mathrm{H}-7$ ), $\delta 4.20$ (glu-anomeric), $\delta 2.98-3.31$ (six sugar proton). ${ }^{13} \mathrm{C}$ NMR data (Table 1 ) displayed the presence of p-hydroxy phenyl unite and glucose moiety. The results of acid hydrolysis produce the presence of glucose, so the structure of compound 9 was determined as 2(4-hydroxyphenyl)ethyl glucopyranoside (Salidroside) which previously isolated from Rhodiola sp. [37].

Compound 10 ( $\beta$-sitosterol): White powder, m.p. $140^{\circ} \mathrm{C}, \mathrm{R}_{\mathrm{f}}: 0.67$ [S6], It was identified by ESI-MS mass spectra which gave molecular ion at $\mathrm{m} / \mathrm{z}$ $414(\mathrm{M}+\mathrm{H})^{+},{ }^{1} \mathrm{H}$ NMR gave signals at $\delta 3.53(1 \mathrm{H}, m, \mathrm{H}-3), \delta 5.36(1 \mathrm{H}, m$, $\mathrm{H}-6), \delta 0.69$ (3H, s, H-18), $\delta 1.03(3 \mathrm{H}, s, \mathrm{H}-19), \delta 0.93(3 \mathrm{H}, d, J=6.6 \mathrm{~Hz}$, $\mathrm{H}-21), \delta 0.89(1 \mathrm{H}, d d, J=15.6,8.4 \mathrm{~Hz}, \mathrm{H}-22), \delta 0.85(3 \mathrm{H}, d, J=7.0 \mathrm{~Hz}$, $\mathrm{H}-26), \delta 0.83$ (3H, $d, J=7.0 \mathrm{~Hz}, \mathrm{H}-27), \delta 0.89$ (3H, $t, J=7.7 \mathrm{~Hz}, \mathrm{H}-29$ ). ${ }^{13} \mathrm{C}$ NMR (Table 2), thus compound 10 was identified by ${ }^{1} \mathrm{H}$ NMR and ${ }^{13} \mathrm{C}$ NMR as $\beta$-sitosterol [38].

\section{Cytotoxic activity assay}

Liver cancer is the main leading cause of cancer deaths worldwide. Thus, the present preliminary studies were done on human liver cancer cell line HepG2 cell line in vitro for the anticancer property of the isolated compounds from A. hirtum. All the tested compounds have display differential levels of cytotoxicity against HepG2 cancer cell lines (Figs. 2-4). Most of the isolated compounds demonstrated to be more active on HepG2 cells; compounds 4, 5 and 6 showed a promising cytotoxic activity against hepatocellular carcinoma with inhibitory activity with $\mathrm{IC}_{50}$ values of $3,3.5$ and $7 \mu \mathrm{g} / \mathrm{ml}$, respectively, while compounds $1,7,8,9$ and 10 exhibit cytotoxicity at IC $_{50}$ values of $9,25,26,20$ and $11.5 \mu \mathrm{g} / \mathrm{ml}$, respectively, whereas compounds 2 and 3 showed the lowest cytotoxicity with $\mathrm{IC}_{50}$ values of 50 and $135 \mu \mathrm{g} / \mathrm{ml}$, respectively. Furthermore, the previous elucidated studies revealed that some volatile oils have been exhibited antitumor activity and numerous plant extracts contain a bioactive compound capable of killing malignant cells by apoptosis [25,39]. Apoptosis is a controlled cell death mechanism functional under both normal and pathological conditions during which cells that are damaged or redundant are eliminated within the body. This is particularly important during embryogenesis and early developmental stages when a large
Table 2: ${ }^{13} \mathrm{C}$ NMR of compound $10(300,75 \mathrm{MHz}$, DMSO-d $)$

\begin{tabular}{ll}
\hline Carbon no & $\boldsymbol{\delta}$ \\
\hline 1 & 37.3 \\
2 & 32.0 \\
3 & 75.2 \\
4 & 42.4 \\
5 & 144.6 \\
6 & 122.4 \\
7 & 33.1 \\
8 & 35.6 \\
9 & 50.7 \\
10 & 36.8 \\
11 & 22.4 \\
12 & 40.3 \\
13 & 42.6 \\
14 & 56.6 \\
15 & 25.7 \\
16 & 28.5 \\
17 & 56.1 \\
18 & 12.6 \\
19 & 20.2 \\
20 & 40.1 \\
21 & 21.5 \\
22 & 35.6 \\
23 & 29.7 \\
24 & 50.3 \\
25 & 26.0 \\
27 & 19.2 \\
28 & 19.8 \\
29 & 23.3 \\
\hline in & 11.9 \\
\hline &
\end{tabular}

number of immature neuronal cells are eliminated during formation and maturation of the nervous system [40]. The results suggested that plant phenol, gallic acid, and methyl gallate, may play an important role in the cytotoxic activity of the plant. Bergapten is known to cause chromosome 


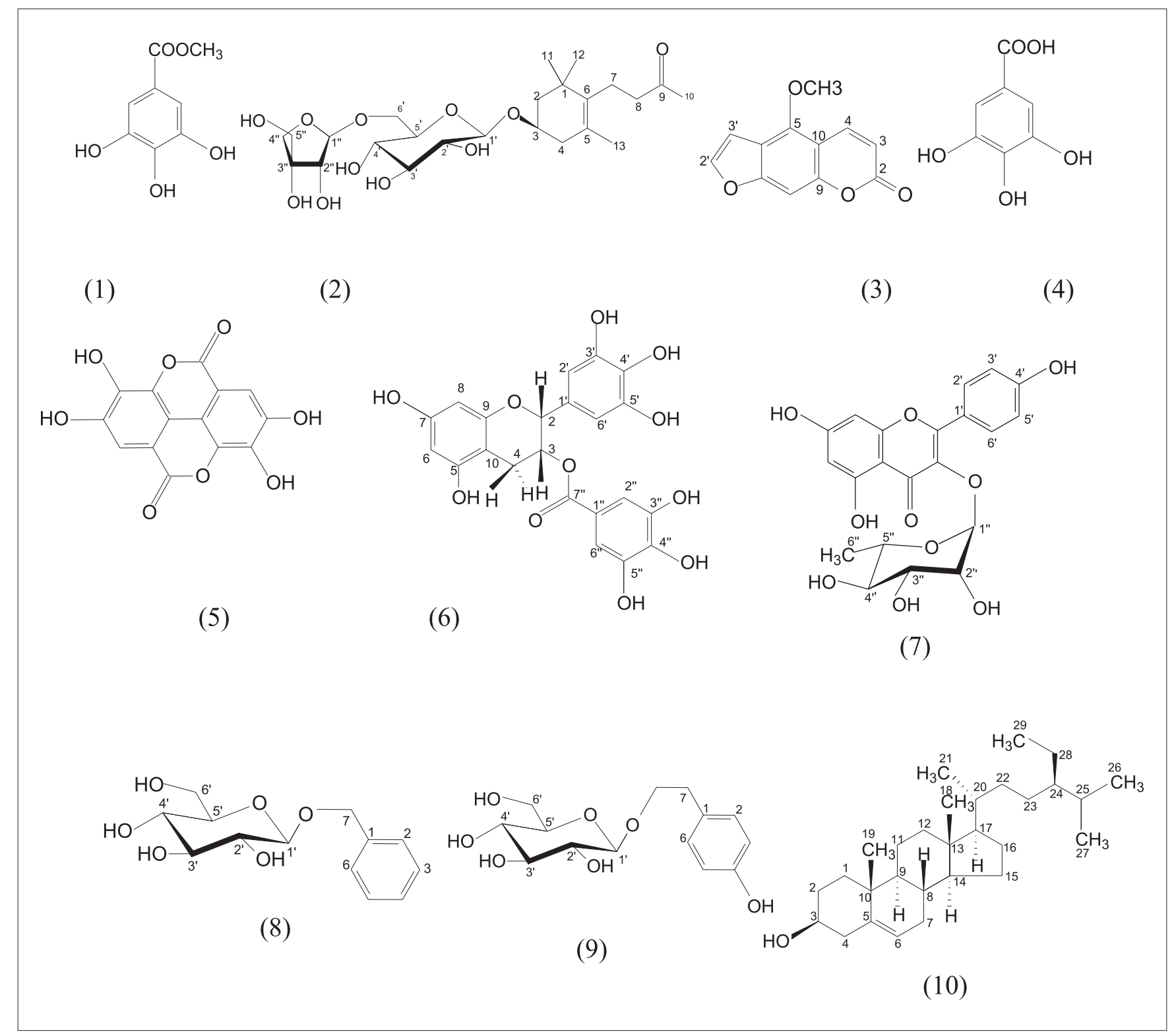

Fig. 1: Chemical skeletons of compounds 1-10

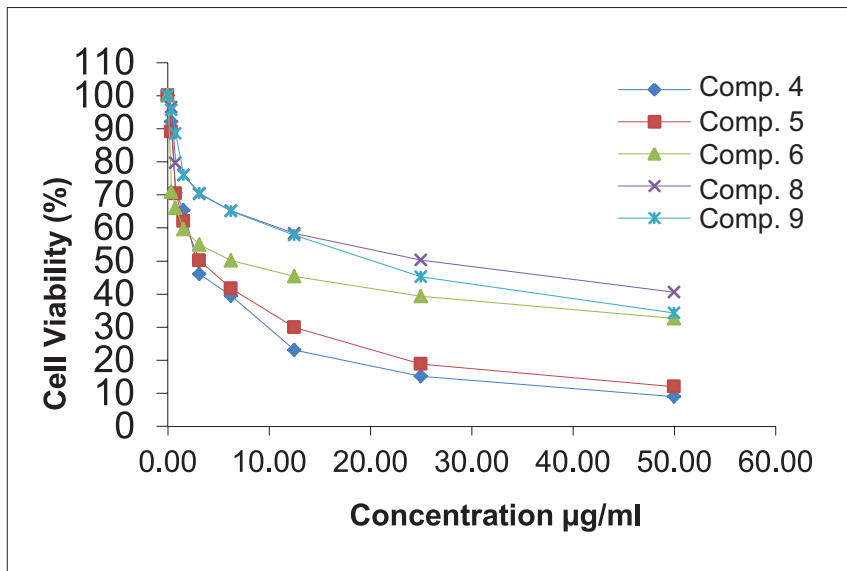

Fig. 2: The cytotoxic activity of compounds. 2 and 3 against HepG2 cancer cell lines. 4, 5, 6, 8 and 9 against HepG2 cancer cell lines

damage and mutagenicity probably due to cross-linkage with DNA, the same mechanism observed for the therapeutic action [41].

\section{Antimicrobial activity}

The antimicrobial activities noticed among the methanol extract and isolated compounds of $A$. hirtum leaves were found to be maximum in ellagic acid against ( $\mathrm{G}-\mathrm{ve}, \mathrm{G}+\mathrm{ve}$ ) bacteria, yeast and fungi with inhibition zones ranged from 8 to $14 \mathrm{~mm}$. Gallic acid showed a characteristic effect against $A$. niger with inhibition zone $(10 \mathrm{~mm})$. On the other hand, the methanolic extract of $A$. hirtum showed a strong activity against S. aureus $(15 \mathrm{~mm})$ followed by activity against C. albicans $(9 \mathrm{~mm})$ and against $P$. aeruginosa $(8 \mathrm{~mm})$. In this study, chloroform extract exhibited activity against $P$. aeruginosa and $S$. aureus with inhibition zones $6 \mathrm{~mm}$ and $10 \mathrm{~mm}$, respectively. Only compounds 4, 5 and 7 exhibited antifungal activity against $A$. niger (Table 3 ).

Methyl gallate exhibited strong antimicrobial activity; it is known to possess growth-inhibiting activity against Escherichia coli, without adversely affecting the growth of lactic acid-producing bacteria, with the activity being more pronounced by the presence of methyl gallate [42]. Antibacterial activity of some plant extracts was interpreted on the basis of the presence of some polyphenols; many studies were referred to that the activities of medicinal plant extracts can be explained by the presence of tannins, flavonoids, polyphenols, saponins and steroids [43]. 
Table 3: Antimicrobial activity of the methanol extract from Abutilon hirtum and its purified compounds

\begin{tabular}{|c|c|c|c|c|c|}
\hline \multirow[t]{2}{*}{ S. No. } & \multirow[t]{2}{*}{ Sample } & \multicolumn{4}{|l|}{ Clear zone (? mm) } \\
\hline & & Pseudomonas aeruginosa* & Staphylococcus aureus** & Candida albicans ${ }^{* * *}$ & Aspergillus niger fungi \\
\hline Control & Methanol $^{\odot}$ & 0 & 0 & 0 & 0 \\
\hline Crude extract & Methanol extract & 8 & 15 & 9 & 0 \\
\hline Crude extract & Chloroform extract & 6 & 10 & 0 & 0 \\
\hline 1 & Compound 1 & 7 & 8 & 5 & 0 \\
\hline 2 & Compound 2 & 9 & 7 & 6 & 0 \\
\hline 3 & Compound 3 & 2 & 3 & 0 & 0 \\
\hline 4 & Compound 4 & 10 & 9 & 5 & 10 \\
\hline 5 & Compound 5 & 12 & 14 & 10 & 8 \\
\hline 6 & Compound 6 & 10 & 11 & 10 & 0 \\
\hline 7 & Compound 7 & 7 & 10 & 5 & 8 \\
\hline 8 & Compound 8 & 9 & 4 & 6 & 0 \\
\hline 9 & Compound 9 & 7 & 5 & 0 & 0 \\
\hline 10 & Compound 10 & 9 & 11 & 8 & 0 \\
\hline
\end{tabular}

${ }^{\odot}$ Control, *(G-ve), ${ }^{* *}(\mathrm{G}+\mathrm{ve}),{ }^{* * *}$ Yeast

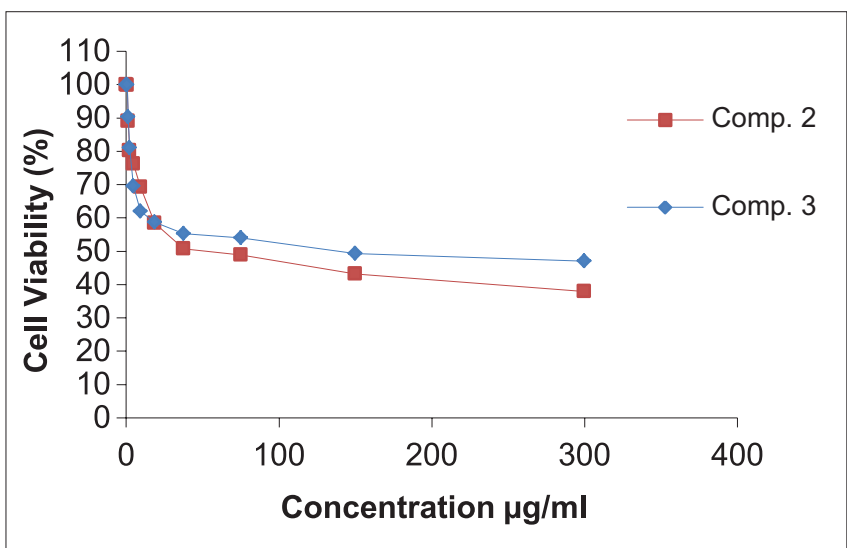

Fig. 3: The cytotoxic activity of compounds. 2 and 3 against HepG2 cancer cell lines

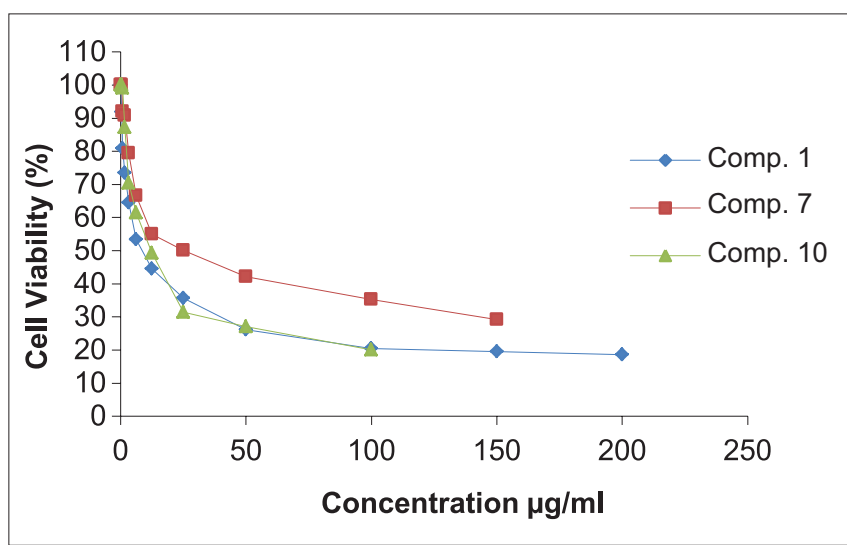

Fig. 4: The cytotoxic activity of compounds. 1, 7 and 10 against HepG2 cancer cell lines

As in tannin, ellagic acid may induce complexation with enzyme or substrate in bacteria cell. Ellagic acid toxicity may be related to its action on the microorganism membranes. Moreover, the ability of ellagic acid to form complexes with the essential metals in bacteria cell account for its toxicity [44].

Polyphenols are known to form with proteins soluble complexes of high molecular weight. Thus, after being adsorbed, the polyphenols will react with the protein moiety of cell enzymes (oxidoreductases) in the cytoplasm and in the cell wall. They may also bind to bacterial adhesions, and so interfering with the availability of receptors on the cell surface [45].
Tannin with gallate group has various physiological functions such as antibacterial, antiallergic, scavenging free radicals, lowering blood pressure, serum and hepatic cholesterol concentrations and increasing fecal sterol excretion in rats with hypercholesterolemia [46]. EGCG is the most abundant, potent polyphenol and is responsible for most of therapeutic benefits (either clinical, animal or cell culture studies). It has various medicinal potentialities which include antimicrobial properties against resistant microorganisms on which it acts by either disrupting the cell membrane, inhibiting the biosynthesis of the cell constituents, cells signaling or DNA damage (described in following sections) [47].

The methanol and chloroform extracts, as well as the pure compounds, found active could be useful for the development of a new antimicrobial drug. However, pharmacological and toxicity studies currently going on in the laboratory capable of confirm this hypothesis.

\section{Antioxidant assessment}

The TAC is a quantitative method for determining the TAC, which is expressed as AAEs. This method based on the reduction of $\mathrm{Mo}(\mathrm{VI})$ to $\mathrm{Mo}(\mathrm{V})$ by the sample and subsequent formation of green phosphate/Mo(V) complex at acid pH. It assesses both water-soluble and fat-soluble antioxidants (TAC). The results indicate higher TAC of the methanol, chloroform extracts and pure compounds, respectively, at low concentration, this method gives a combined measure of the antioxidant activity of the range of chemically various phenolic and flavonoid compounds present in the methanol extract of $A$. hirtum leaves as specified by formation of the reduced phosphomolybdate complex and measured at $(695 \mathrm{~nm})$ as indicated in Table 4 . Under the experimental conditions, all selected samples exhibited antioxidant activities. Furthermore, a significant correlation between the results of these tests was obtained. These results strongly correlate with the total phenolic and flavonoid contents of the samples, and according to the obtained results, its phenolics and flavonoids are the major phytochemicals responsible for antioxidant activity in the investigated samples. The TAC of $A$. hirtum leaves ranges from $810.35-341.15 \%$ of standard ascorbic acid at a concentration of $100 \mu \mathrm{g} / \mathrm{ml}$ of the sample in methanol (Table 4). Accordingly, it is clear that the isolated compounds have high redox potentials and can act as reducing agent, hydrogen donor, and singlet oxygen quencher. Salidroside, a phenylpropanoid glycoside, shows potent antioxidant property which may due to it have interfered in the intracellular excess ROS thereby down-regulated the ROS signaling pathway. Hu's works showed that salidroside induced apoptosis in cancer cells and the cytotoxic effects of salidroside were very strong which may be important for the anticancer activity observed in liver cancer cells [48]. In addition to being used as medicinal herbs, this plant could also be used as a rich source of natural antioxidants to delay the oxidative deterioration of foods. It is also suggested that 
Table 4: The TAC using Ascorbic acid as standard

\begin{tabular}{ll}
\hline Sample & TAC (mg AAE/g sample) ${ }^{@}$ \\
\hline Methanol extract & $497.33 \pm 1.15$ \\
Chloroform extract & $442.00 \pm 2.00$ \\
Compound 1 & $695.0 \pm 1.10$ \\
Compound 2 & $341.15 \pm 1.75$ \\
Compound 3 & $568.45 \pm 1.65$ \\
Compound 4 & $743.30 \pm 1.15$ \\
Compound 5 & $810.35 \pm 1.55$ \\
Compound 6 & $677.75 \pm 1.20$ \\
Compound 7 & $362.25 \pm 1.95$ \\
Compound 8 & $450.0 \pm 2.00$ \\
Compound 9 & $782.10 \pm 2.10$ \\
Compound 10 & $587.75 \pm 2.25$ \\
\hline
\end{tabular}

Results are expressed as mean values \pm standard deviation $(\mathrm{n}=3)$. ${ }^{\circledR}$ Total antioxidant capacity values are expressed as $\mathrm{mg}$ ascorbic acid equivalent/g extract (mg AAE/g sample).

$\beta$-sitosterol can protect against oxidative stress through modulation in the levels of antioxidant enzymes [49]. Fatima et al., in an in vitro study revealed that, due to its antioxidant property, EGCG is an inhibitor of ROS and reactive nitrogen intermediates pathways [50]. Aerobic organisms consume a large amount of molecular oxygen to maintain cellular metabolic processes. Reactive oxygen species (ROS) are the section of various metabolic processes for which the terminal electron acceptor is the molecular oxygen $\left(\mathrm{O}_{2}\right)$ that acts as a thermodynamic basin. ROS generally causes harm effect to living organisms and thus, the induced oxidative stress due to the formation of ROS is attributed to the damage of biological systems in the body, supporting the development of various diseases such as cancer and also forced the aging process [51]. Patra et al. (2010) confirmed that $\beta$-sitosterol reduced carcinogen-induce cancer of the colon. It also shows antiinflammatory, antipyretic, antiarthritic, antiulcer, insulin releasing, and estrogenic lowering property [38]. Gallic acid is such a polyphenolic compound with reported anticancer activities on different cancer cells. It is also well known for its protective activity on normal cells which made gallic acid as a necessary compound for cancer therapy [52]. The impact of the study will pave a way to develop gallic acid as a significant therapeutic agent to treat and prevent cancer. Ellagic acid is a potent antioxidant, a phenolic compound known as a potent anticarcinogenic, antimutagenic compound [53]. Research shows that ellagic acid, which is an anti-carcinogenic, inhibits the growth of cancer cells; it also causes apoptosis or normal cell death in those cancer cells [54].

\section{Structure activity relationship}

Inoue et al. (1995) elucidated that the carboxyl group of gallic acid is presumably implicated in distinguishing between normal and cancer cells and the three adjacent phenolic hydroxyl groups should be essential to the cytotoxicity [55]; this confirms the strong cytotoxic activity of gallic acid.

Radical-scavenging activity of phenolics depends, among other factors, on the number and position of hydroxyl $(-\mathrm{OH})$ group substituent in the molecules as which called on the antioxidant activity of the flavonoids is known to be associated with the number of free hydroxyl groups $(\mathrm{OH})$; moreover the presence of the carboxyl, alkyl or other groups affects the antioxidant activity of phenol compounds which describes the obtained antioxidant activity results for compounds 1, 4, 5 and 6. The maximum effectiveness for radical scavenging apparently requires the two hydroxyl groups in the ortho-diphenolic arrangement in the $\mathrm{B}$ ring and 3-OH group attached to the 2,3-double bond and adjacent to the 4-carbonyl in the $\mathrm{C}$ ring. The glycosylation of flavonoids as in case of kaempferol-3-0- $\alpha$-L-rhamnoside reduces their activity when compared to the corresponding aglycones [56]. From our findings, it seems that free $\mathrm{OH}$ group in positions 5,7 , and 4', especially position 7 , may potentiate the activity against the radical with respect to the presence of glucoside groups, their types, numbers, and positions. While free $\mathrm{OH}$ group in positions 5 and 4' may be associated with the inhibitory activity against radicals. The blocking of position 3 or the steric hindrance of $\mathrm{OH}$ group by glucoside groups may lead to dramatic decrease in the activities as shown in compound 7.

Thus, the TAC of methanol extract (polar extract) and isolated pure compounds of $A$. hirtum leaves showed that this plant can be one of the potential sources of safer natural antioxidants while stronger restrictions are encountered on their application. Hence, replacement of synthetic antioxidants with secondary metabolite phytochemicals exhibiting authoritative and effective antioxidant activities (because of their aspects on human health) from abundantly available plant sources such as $A$. hirtum may be advantageous.

\section{CONCLUSION}

As a conclusion, 10 compounds, methyl gallate (1), cuneataside E (2), bergapten (3), gallic acid (4), ellagic acid (5), EGCG (6), kaempferol 3-O- $\alpha$-L-rhamnoside (7), benzyl-1-O- $\beta$-D-glucopyranoside (8), salidroside (9), and $\beta$-sitosterol (10) have been successfully isolated from $A$. hirtum leaves. Our results revealed that compounds 4, 5 and 6 showed significant cytotoxic activity against liver carcinoma; this causes these compounds useful as chemotherapeutics agents not only for their cytotoxic activity but also for their antioxidant potential; these compounds may a function in a synergistic manner. Furthermore, ellagic acid is the most antimicrobial active agent among the isolated compounds against four different microbial strains. However, further studies must be necessary to elucidate the mechanism situated with these activities. This report may serve as a footprint concerning the biological and pharmacological activities of A. hirtum leaves.

\section{REFERENCES}

1. Kutluk T, Kars A. General Knowledge about cancer. Ankara; Turkey Cancer Investigation and Fight Society Publications; 1998. p. 7-15.

2. Frankič T, Voljč M, Salobir J, Rezar V. Use of herbs and spices and their extracts in animal nutrition. Acta Agric Slov 2009;94(2):95-102.

3. Brenzel KN, editor. Sunset Western Garden Book. $6^{\text {th }}$ ed. Menlo Park, Calif: Sunset Publishing Corporation; 1995.

4. Esteves GL, Krapovickas A. New species of Abutilon (Malvaceae) from Sao Paulo State. Braz Kew Bull 2002;57(2):479-82.

5. Abdul Rahuman A, Gopalakrishnan G, Venkatesan P, Geetha K. Isolation and identification of mosquito larvicidal compound from Abutilon indicum (Linn.) Sweet. Parasitol Res 2008;102(5):981-8.

6. Singh MP, Panda H. Medical Herbs with Their Formulations. New Delhi, India: Daya Publishing House; 2005. p. 32-3.

7. Ahmed Z, Kazmi SN, Malik A. New pentacyclic triterpene from Abutilon pakistanicum. J Nat Prod 1990;53:1342-4.

8. Sharma PV, Ahmed ZA. Two sesquiterpene lactones from Abutilon indicum. Phytochemistry 1989;28(12):3525.

9. Evans WC. Trease and Evans, Pharmacognosy. $15^{\text {th }}$ ed. Edinburgh, London, New York, Toronto: Elsevier; 2002. p. 476

10. Sharma PV, Ahmed ZA, Sharma VV. Analgesic constituent of Abutilon indicum. Indian Drugs 1989;26(7):333.

11. Jam PK, Sharma TC, Bokadia MM. Chemical Investigation of Abutilon indicum. Acta Cienc Indica 1982;8(3):136-9.

12. Porchezhian E, Ansari SH. Hepatoprotective activity of Abutilon indicum on experimental liver damage in rats. Phytomedicine 2005; $12(1-2): 62-4$

13. Lipinski B. Pathophysiology of oxidative stress in diabetes mellitus. J Diabetes Complications 2001;15(4):203-10.

14. Fu CD, Hong YF. Research on chemical composition of Abutilon theophrasti Medic. Foreign Med Sci 1993;15:4-7.

15. Huxley A, Griffiths M, Levy M. Dictionary of Gardening. London: The MacMillan Press Limited; 1992. p. 8-9.

16. Kassem HA. Investigation of lipids, mucilage and cytotoxic activity of Abutilon hirtum (Lam.) Grown in Egypt. Bull Fac Pharm Cairo Univ 2001;39(1):156-9

17. Kirtikar KR, Basu BD. Indian Medicinal Plants. $2^{\text {nd }}$ ed., Vol. I. Dehradun: Bishan Singh and Mahendrapal Singh; 1994. p. 314-7.

18. Nadakarni AK. Indian Materia Medica. Bombay: Popular Prakashan (Pvt) Ltd.; 1995. p. 8-9.

19. Chatterjee A, Prakash C. The Treatise on Indian Medicinal Plants. New Delhi: Publication \& Information Directorate; 1991. p. 174-5.

20. Raddy S, Kumar AS, Gnananath K, Ganapaty S. Hepatoprotective 
potential of Abutilon hirtum sweet leaves in carbon tetrachloride induced hepatotoxicity. Asian J Biomed Pharm Sci 2011;1(3):26-31.

21. Chandan BK, Saxena AK, Shukla S, Sharma N, Gupta DK, Singh K, et al. Hepatoprotective activity of Woodfordia fruticosa Kurz flowers against carbon tetrachloride induced hepatotoxicity. J Ethnopharmacol 2008;119(2):218-24.

22. Jain A, Soni M, Deb L, Jain A, Rout SP, Gupta VB, et al. Antioxidant and hepatoprotective activity of ethanolic and aqueous extracts of Momordica dioica Roxb. Leaves. J Ethnopharmacol 2008;115(1):61-6.

23. Jain R, Jain SC, Arora R. A new cholestane derivative of Abutilon bidentatum Hochst. and its bioactivity. Pharmazie 1996;51(4):253.

24. Hamed MM, Refahy LA, Abdel-Aziz MS. Evaluation of antimicrobial activity of some compounds isolated from Rhamnus cathartica (L). Orient J Chem 2015;31(2):1133-40.

25. Hamed M, Mohamed M, Refai L, Hammam O, El-Ahwany E, Salah F, et al. The active constituents of Pelargonium zonale induced cytotoxicity in human hepatoma cell line HepG2. Int J Pharm Appl 2015;6(1):10-9.

26. Hassanein H, El-Ahwany E, Salah F, Hammam O, Refai L, Hamed M. Extracts of five medicinal herbs induced cytotoxicity in both hepatoma and myloma cell lines. Cancer Sci Ther 2010;3(10):239-43.

27. Prieto P, Pineda M, Aguilar M. Spectrophotometric quantation of antioxidant capacity through the formation of a phosphomolybdenum complex: Specific application to the determination of vitamin E. Anal Biochem 1999;269(2):337-41.

28. Mosmann T. Rapid colorimetric assay for cellular growth and survival: Application to proliferation and cytotoxicity assays. J Immunol Methods 1983;65(1-2):55-63.

29. Bauer AW, Kirby WM, Sherris JC, Turck M. Antibiotic susceptibility testing by a standardized single disk method. Am J Clin Pathol 1966:45(4):493-6.

30. Tan YP, Chan EW, Lim CS. Potent quorum sensing inhibition by methyl gallate isolated from leaves of Anacardium occidentale (L) (cashew). Chiang Mai J Sci 2015;42(3):650-6.

31. Chang J, Case R. Phenolic glycosides and ionone glycoside from the stem of Sargentodoxa cuneata. Phytochemistry 2005;66(23):2752-8.

32. Choi BR, Hong SS, Han XH, Hwang JS, Lee MH, Hur JD, et al. Antioxidant constituents from Portulaca oleracea. Nat Prod Sci 2005;11(4):229-32

33. Eldahshan OA. Isolation and structure elucidation of phenolic compounds of carob leaves grown in Egypt. Curr Res J Biol Sci 2011;3(1):52-5

34. Mahajan A, Pai N. Simultaneous isolation and identification of phutoconstituents from Terminalia chebula by preparative chromatography. J Chem Pharm Res 2010;2(5):97-103.

35. Granja-Perez PE, Gamboa-Angulo MM, Escalanye-Erosa F, Pena-Rodrigues LM. Identification of kaempherol 3-O- $\alpha-\mathrm{L}-$ rhamnopyranoside as biotransformation product of Alternaria tagetica. Rev Soc Quim Mexico 1999;43(6):188-91.

36. Wen Q, Lin X, Liu Y, Xu X, Liang T, Zheng N, et al. Phenolic and lignan glycosides from the butanol extract of Averrhoa carambola $\mathrm{L}$. Root. Molecules 2012;17(10):12330-40.

37. Wiedenfeld H, Dumaa M, Malinowski M, Furmanowa M, Narantuya S. Phytochemical and analytical studies of extracts from Rhodiola rosea and Rhodiola quadrifida. Pharmazie 2007;62(4):308-11.
38. Patra A, Jha S, Murthy PN, Sharone A. Isolation and characterization of stigmast-5-en-3 $\beta$-ol ( $\beta$-sitosterol) from the leaves of Hygrophila spinosa T. Anders. Int J Pharm Sci Res 2010;1(2):95-100.

39. Hamed MM. Volatile oils from Pelargonium zonale and its cytotoxic effect on tumor cells. Bull Fac Pharm Cairo Univ 2007;45(3):297-300.

40. Burek MJ, Oppenheim RW. Programmed cell death in the developing nervous system. Brain Pathol 1996;6(4):427-46.

41. Muller M, Byres M, Jaspars M, Kumarasamy Y, Middleton M, Nahar L, et al. 2D NMR spectroscopic analyses of archangelicin from the seeds of Angelica archangelica. Acta Pharm 2004;54(4):277-85.

42. Ahn YJ, Lee CO, Kweon JH, Ahn JW, Park JH. Growth-inhibitory effects of Galla Rhois-derived tannins on intestinal bacteria. J Appl Microbiol 1998;84(3):439-43.

43. Aliyo AB, Musa AM, Abdullahi MS, Oyewale AO. Phytochemicals and antimicrobial properties of Ludwigia suffraticosa. Int J Pure Appl Sci 2008;2(4):1-5.

44. Misanori A, Kosuyasu F, Osumu Y, Takashi O, Kiji I. Antibacterial action of several tannins against Staphylococcus aureus. J Antimicrob Chemother 2001;48(4):487-91.

45. Machado TB, Pinto AV, Pinto MC, Leal IC, Silva MG, Amaral AC, et al. In vitro activity of Brazilian medicinal plants, naturally occurring napthoquinones and their analogues, against methicillinresistant Staphylococcus aureus. Int J Antimicrob Agents 2003;21(3):279-84

46. Aqil F, Khan MS, Owais M, Ahmad I. Effect of certain bioactive plant extracts on clinical isolates of beta-lactamase producing methicillin resistant Staphylococcus aureus. J Basic Microbiol 2005;45:106-14.

47. Sharangi A. Medical and therapeutic potentialities of tea (Camellia sinensis L.) - A review. Food Res Int 2009;42:529-35.

48. Hu X, Zhang X, Qiu S, Yu D, Lin S. Salidroside induces cell-cycle arrest and apoptosis in human breast cancer cells. Biochem Biophys Res Commun 2010;398(1):62-7.

49. Vivancos M, Moreno JJ. Beta-Sitosterol modulates antioxidant enzyme response in RAW 264.7 macrophages. Free Radic Biol Med 2005;39(1):91-7.

50. Fatima Z, Hameed S, Islam N. Green tea polyphenol (EGCG) is a better inhibitor of TNF- $\alpha$ and MTB 85B antigen in human monocytes than known antioxidants and antibiotics. J Infect Dis 2013;112:131-7.

51. Halliwell B. Free radicals, antioxidants, and human disease: Curiosity, cause, or consequence? Lancet 1994;344(8924):721-4.

52. Li T, Zhang X, Zhao X. Powerful protective effects of gallic acid and tea polyphenols on human hepatocytes injury induced by hydrogen peroxide or carbon tetrachloride in vitro. J Med Plants Res 2010;4(3):247-54

53. Rice-Evans C, Miller NJ, Paganga G. Structure antioxidant activity relationships of flavonoids and phenolic acids. Free Radic Biol Med 1996;20(7):933-56.

54. Loarca-Piña G, Kuzmicky PA, de Mejía EG, Kado NY. Inhibitory effects of ellagic acid on the direct-acting mutagenicity of aflatoxin B1 in the Salmonella microsuspension assay. Mutat Res 1998 26;398(1-2):183-7.

55. Inoue M, Suzuki R, Sakaguchi N, Li Z, Takeda T, Ogihara Y, et al. Selective induction of cell death in cancer cells by gallic acid. Biol Pharm Bull 1995;18(11):1526-30.

56. Suzuki M, Kumazawa N, Ohta S, Kamogawa A, Shinoda M. Protective effects of antioxidants on experimental liver injuries. Yakugaku Zasshi 1990;110(9):697-701. 